\title{
Optimal reactive power dispatch by chaotic biogeography based optimization
}

\section{- Truong Xuan Quy}

- Vo Ngoc Dieu

Ho Chi Minh city University of Technology, VNU-HCM, Vietnam

(Manuscript Received on July 15, 2015, Manuscript Revised August 30, 2015)

\section{ABSTRACT}

This paper proposes a chaotic biogeography based optimization (CBBO) for solving optimal reactive power dispatch (ORPD) problem. Based on biogeography based optimization (BBO) theory proposed by Dan Simon in 2008, a new artificial intelligence with full models and equations have been used to achieve the best solution for objective function of ORPD such as total power loss, voltage deviation and voltage stability index while satisying various constraints of power balance, voltage limits, transformers tap changer limits and switchable capacitor bank limits. The BBO has been enhanced its search ability by adding chaotic theory. Therefore, the proposed CBBO can obtain better solutiong quality than $B B O$ for optimization problems. The proposed method has been tested on the IEEE-30 and IEEE-118 bus systems and the obtained results have been verified with other methods. The result comparison has indicated that the CBBO can be a promise method for dealing the ORPD problem

Keywords: Optimal Reactive Power Dispatch, Biogeography Based Optimization, Chaos Theory, Power loss, Voltage Deviation, Voltage Stability Index

\section{INTRODUCTION}

The main objective of optimal reactive power dispatch (ORPD) [1] in electrical power system is to minimize the objective function via the optimal adjustment of the power system control variables, while at the same time satisfying various equality and inequality constraints. Some objective functions in ORPD to evaluate the quality of power system is real power loss, voltage deviation at load buses [2], voltage stability index [3]. The equality constraints are the power flow balance equations, while the inequality constraints are the limits on the control variables and the operating limits of the power system dependent variables.
The problem control variables include the generator bus voltages, the transformer tap settings, and the reactive power of shunt compensator, while the problem dependent variables include the load bus voltages, the generator reactive powers, and the power line flows.

There are various techniques ranging were introduced to solve ORPD, from conventional methods to artificial intellgence based methods. These conventional methods have been used for approaching the ORPD is linear programming (LP) [4], mixed-integer programming (MIP) [5], 
interior point method (IPM) [6], dynamic programming (DP) [7] and quadratic programming (QP) [8]. The convetinal optimizations are easily to be carried out, the results is acceptable but can be trapped in local minima and this optimization can not act on the discrete variables. Recently, meta-heuristic search methods become more popular in doing with ORPD. Several methods, most of them are based on the biological model like evolutionary and behavior in species, were used such as evolutionary programming (EP) [9], genetic algorithm (GA) [10], differential evolution (DE) [11], ant colony optimization (ACO) [12] and particle swarm optimization (PSO) [13]. These methods can improve the solutions for ORPD although it is more complex and slow in performance.

In this project, we discuss about an evolutionary algorithm that was found in 2008 by Dan Simon [14], called Biogeography Based Optimization. It is based on the migration and mutation of species in natural and the status of ecosystem in different time. By supplying the full theory and model of CBBO, we proved the useful of this algorithm by testing on IEEE-30 bus system and IEEE-118 bus system. The results is compared with the other paper to evaluate the advantage or disadvantage of this method.

\section{FORMULATION OF ORPD}

The ORPD problem is built based on the mathematics concepts

$$
\begin{aligned}
& \text { Min } F(x, u) \\
& g(x, u)=0 \\
& h(x, u) \leq 0
\end{aligned}
$$

where $F(x, u)$ called the objective function whose output is the minimum value we want. $\mathrm{g}(x, u)$ is the equality constraints and $\mathrm{h}(x, u)$ is the inequality constraints.
Applied the above to the ORPD problem, $x$ is the containing vector of the controlled variables: the voltage and phase of load, reactive power of the generators and real power of slack bus.

$$
x=\left(\mathrm{P}_{G 1}, \theta_{2}, \ldots, \theta_{N}, V_{L 1}, \ldots, V_{L N L}, Q_{g 1}, \ldots, Q_{g n g}\right)^{T}
$$

$u$ is the containing vector of the controlling variables: voltage of generators, tap-setting of transformers and the reactive power at compensator.

$$
u=\left(V_{g 1} \ldots V_{g n g}, T_{1} \ldots T_{N T}, Q_{c 1} \ldots Q_{c N c}\right)^{T}
$$

The objective function is depended on the target of optimization. Normally, there are three functions used:

- The total active power loss in transmission:

$$
F=P L=\sum_{k \in N b r} g_{k}\left(V_{i}^{2}+V_{j}^{2}-2 V_{i} V_{j} \cos \theta_{i j}\right)
$$

where $g_{k}$ is the conductance of branch $k$, $V_{i}$ is the voltage magnitude at bus $i$ and $\theta_{i j}$ is the voltage angle different between bus $i$ and $j$.

- Voltage deviation at loaded buses for voltage profile improvement:

$$
V D=\sum_{i=1}^{N}\left|V_{i}-V_{i}^{s p}\right|
$$

where $V_{i}^{s p}$ is the standard value to evaluate the deviation, normally set at 1 p.u.

- Voltage stability index for voltage stability enhancement:

$$
F(x, u)=L_{\max }=\max \left\{L_{i}\right\} ; i=1, \ldots, N_{d}
$$

where $g(x, u)$ is the equality constraints, it follow the power conservation law:

$$
P_{G}=P_{D}+P_{L}
$$

This equation can be spread:

$$
\left\{\begin{array}{l}
P_{g i}-P_{d i}-v_{i} \sum v_{j}\left(g_{i j} \cos \theta_{i j}+B_{i j} \sin \theta_{i j}\right)=0 \\
Q_{g i}-Q_{d i}-v_{i} \sum v_{j}\left(g_{i j} \sin \theta_{i j}+B_{i j} \cos \theta_{i j}\right)=0
\end{array}\right.
$$


where $g_{i i}, B_{i i}$ are the transfer conductance and susceptance between bus $i$ and bus $j ; P_{d i}, Q_{d i}$ are the real and reactive power outputs of generating at bus $i ; P_{g i}, Q_{g i}$ are the real and reactive power outputs of generating unit $i$.

This equality constraints is checked by running Power Flow by Newton-Raphson method in Matlab.

$h(x, u)$ is the inequality constraints represented as follows:

a) The power limitations:

$$
\left\{\begin{array}{c}
P_{g s \text { miack }}^{\min } \leq P_{g s l a c k} \leq P_{g s l a c k}^{\max } \\
Q_{g i}^{\min } \leq Q_{g i} \leq Q_{g i}^{\max }
\end{array}\right.
$$

b) The voltage limitations:

$$
V_{i}^{\min } \leq V_{i} \leq V_{i}^{\max }
$$

c) Transformers tap-settings constraints:

$$
T_{i}^{\min } \leq T_{i} \leq T_{i}^{\max }
$$

d) The compensator capacitor limitations:

$$
Q_{c}^{\min } \leq Q_{c} \leq Q_{c}^{\max }
$$

e) The power flow limitations:

$$
S_{i} \leq S_{i}^{\max }
$$

where $S_{i}$ is the maximum power flow between bus $i$ and bus $j$.

$$
S_{i}=\max \left\{\left|S_{i j}\right|,\left|S_{j i}\right|\right\}
$$

To check the inequality constraint, we use the Static Square method. The objective function $F$ not only have the output value but also adding the penalty function $k \sum\left(f\left(x_{i}\right)\right)^{2}$ with:

$$
f(x)=\left\{\begin{array}{cc}
0 & x_{\min } \leq x_{i} \leq x_{\max } \\
\left(x_{i}-x_{\max }\right)^{2} & x_{i}>x_{\max } \\
\left(x_{\min }-x_{i}\right)^{2} & x_{i}<x_{\min }
\end{array}\right.
$$

So with the penalty function, the objective function will be rewritten as:

$$
F_{p}=F+k \sum_{i=1}^{N G} f\left(Q_{g i}\right)+k \sum_{i=1}^{N P Q} f\left(\mathrm{~V}_{i}\right)+k \sum_{i=1}^{N l} f\left(\mathrm{~S}_{i}\right)
$$

\section{CHAOTIC BIOGEOGRAPHY BASED OPTIMIZATION}

\subsection{Migration [14]}

Mathematical models of biogeography describe how species migrate from one island to another, how new species arise, and how species become extinct. Geographical areas that are well suited as residences for biological species are said to have a high habitat suitability index (HSI) [14]. The variables that characterize habitability are called suitability index variables (SIVs) [14]. SIVs can be considered the independent variables of the habitat, and HSI can be considered the dependent variable. Habitats with a high HSI tend to have a large number of species, while those with a low HSI have a small number of species. Habitats with a high HSI have many species that emigrate to nearby habitats, simply by virtue of the large number of species that they host. Habitats with a high HSI have a low species immigration rate because they are already nearly saturated with species. Therefore, high HSI habitats are more static in their species distribution than low HSI habitats. By the same token, high HSI habitats have a high emigration rate; the large number of species on high HSI islands have many opportunities to emigrate to neighboring habitats.

The parameters below is used for BBO investigation:

- Habitat suitability index (HSI): to evaluate the capability of the island for the creatures.

- Suitability index variables (SIVs): the independent variables such as rainfall, temperature, humidity...

- Immigration rate: $\lambda$

- Emigration rate: $\mu$ 


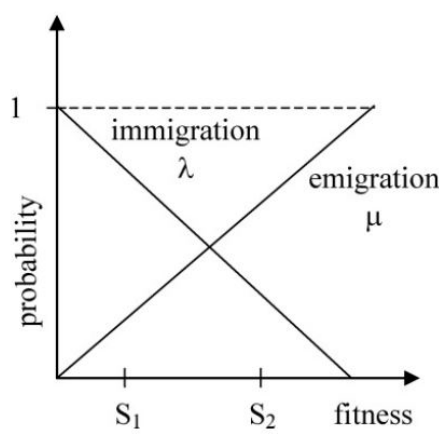

Figure 1. Linear curve of fitness - migration

Considering the immigration curve. The maximum possible immigration rate to the habitat is which occurs when there are zero species in the habitat. As the number of species increases, the habitat becomes more crowded, fewer species are able to successfully survive immigration to the habitat, and the immigration rate decreases. The largest possible number of species that the habitat can support is at which point the immigration rate becomes zero.

Now considering the emigration curve. If there are no species in the habitat then the emigration rate must be zero. As the number of species increases, the habitat becomes more crowded, more species are able to leave the habitat to explore other possible residences, and the emigration rate increases. The maximum emigration rate is which occurs when the habitat contains the largest number of species that it can support.

The equilibrium number of species is, at which point the immigration and emigration rates are equal. However, there may be occasional excursions from due to temporal effects. Positive excursions could be due to a sudden spurt of immigration, or a sudden burst of speciation. Negative excursions from could be due to disease, the introduction of an especially ravenous predator, or some other natural catastrophe. It can take a long time in nature for species counts to reach equilibrium after a major perturbation.
With the linear curves, the value of $\lambda, \mu$ whether there are s species in habitat can be written as:

$$
\mu_{s}=\frac{E s}{n} \quad \lambda_{s}=I\left(1-\frac{s}{n}\right)
$$

where:

- $\mathrm{E}$ is the highest emigration rate

- I is the highest immigration rate

- $\mathrm{n}$ is the maximum species in habitat

We use the emigration and immigration rates of each solution to probabilistically share information between habitats. If a given solution is selected to be modified, then we use its immigration rate $\lambda$ to probabilistically decide whether or not to modify each suitability index variable (SIV) in that solution. If a given SIV in a given solution $S_{i}$ is selected to be modified, then we use the emigration rates $\mu$ of the other solutions to probabilistically decide which of the solutions should migrate a randomly selected SIV to solution $S_{i}$.

The BBO migration strategy is similar to the global recombination approach of the breeder GA and evolutionary strategies in which many parents can contribute to a single off-spring, but it differs in at least one important aspect. In evolutionary strategies, global recombination is used to create new solutions, while BBO migration is used to change existing solutions. Global recombination in evolutionary strategy is a reproductive process, while migration in BBO is an adaptive process; it is used to modify existing islands.

As with other population-based optimization algorithms, we typically incorporate some sort of elitism in order to retain the best solutions in the population. This prevents the best solutions from being corrupted by immigration.

\subsection{Mutation [14]}


Now, consider the probability $\mathrm{P}_{s}$ that the habitat contains exactly $S$ species. By calculate the limit of the changing time of habitat, $\Delta t \rightarrow 0$ , we have the probability equation:

$P_{s}=\left\{\begin{array}{cc}-\left(\lambda_{s}+\mu_{s}\right) P_{s}+\mu_{s+1} P_{s+1} & S=0 \\ -\left(\lambda_{s}+\mu_{s}\right) P_{s}+\lambda_{s-1} P_{s-1}+\mu_{s+1} P_{s+1} & 1 \leq S \leq S_{\max }-1 \text { (18) } \\ -\left(\lambda_{s}+\mu_{s}\right) P_{s}+\lambda_{s-1} P_{s-1} & S=S_{\max }\end{array}\right.$

If a given solution $S$ has a low probability $\mathrm{P}_{s}$ , then it is surprising that it exists as a solution. It is likely to mutate to some other solution. This can be implemented as a mutation rate $m$ that is inversely proportional to the solution probability:

$$
m(\mathrm{~s})=\mathrm{m}_{\max }\left(\frac{1-P_{s}}{P_{\max }}\right)
$$

where $\mathrm{m}_{\max }$ is the user-defined parameters.

This mutation scheme tends to increase diversity among the population. Without this modification, the highly probable solutions will tend to be more dominant in the population. This mutation approach makes low HSI solutions likely to mutate, which gives them a chance of improving. It also makes high HSI solutions likely to mutate, which gives them a chance of improving even more than they already have.

\subsection{Application BBO to ORPD problem}

Step 1: Set the initial value for the BBO variables. The $\mathrm{i}$-th species in $\mathrm{BBO}$ is a vector of controlling variables:

$$
X_{i d}=\left[V_{G 1} \ldots V_{G N G}, Q_{C 1} \ldots Q_{C N C}, T_{1} \ldots T_{N T}\right]
$$

The starting value of $X_{i d}$ is defined by:

$$
X_{i d}=X_{i d}^{\min }+\operatorname{rand}\left(\mathrm{X}_{i d}^{\max }-\mathrm{X}_{i d}^{\min }\right) \quad \operatorname{rand} \in[0 ; 1]
$$

Step 2: Set the value of BBO algorithm.

Step 3: Run the Power-flow by NewtonRaphson method and check the constraint of controlling variables.

Step 4: Calculate the fitness value and compute $\lambda, \mu$.

Step 5: Do the migration step

Step 6: Do the mutation step
Step 7: Back to the step 3 for the next iteration.

If the variables after step 5 and 6 is not satisfied the constraints, we optimize them by set the threshold for the variables:

$$
\begin{cases}X=X_{\max } & X>X_{\max } \\ X=X_{\min } & X<X_{\min }\end{cases}
$$

\subsection{Chaos theory and application in BBO algorithm}

In BBO algorithm, we used the random value to define whether migration, mutation or not. It is absolutely incidental process. Various researches before and my results have pointed that this process complied with Normal (Gaussian Distribution) [15]. The solutions complied with this distribution have very high probability near average point, means that the solutions is concentrated at a specific value which is not the minimum value. (see the Figure 2)

To demolish this disadvantage of BBO, chaos theory was used to supply the comparing value in migration or mutation step. Chaos theory is used to research about systems that seem to be chaotic but can be predicted. This is applied in dynamic systems that is sensitive with initial conditions and have unlimited dimensions. This is popular applied in Soil Mechanics, Solar-system, Liquid convection, Geography and Economics.

A chaotic map in this paper is a reflect: $[0,1] \rightarrow[0,1]$ by the recursive function: $x(n+1)=F(x(n))$ with $x(n)$ is the value of chaotic map at $\mathrm{n}$-th iteration. The orbit of function can be easily predict by the characteristics of value and convergence. Each chaotic map has unique characteristics and with the different initial values, we have the different displays of the graph of function. The chaotic maps used in this project are list below [16].

- Chebyshev: 
$x_{i+1}=\cos (i \cdot a \cos (x(i))$

- Circle:

$$
x_{i+1}=\bmod \left(x_{i}+\Omega-\frac{K}{2 \pi} \sin (2 \pi x(i)), 1\right)
$$

- Gauss:

$$
x_{i+1}=e^{-\alpha x(i)^{2}}-\beta
$$

- Iterative:

$$
x_{i+1}=\left(\frac{\alpha \pi}{x(i)}\right)
$$

- Logistic:

$$
x_{i+1}=\alpha x_{i}\left(1-x_{i}\right) \quad \alpha \leq 4
$$

- Piecewise:

$$
x_{i+1}=\left\{\begin{array}{l}
\frac{0.4-x(i)}{0.4} x(i) \in(0,0.4) \\
\frac{0.5-x(i)}{0.1} x(i) \in(0.4,0.5) \\
\frac{0.6-x(i)}{0.1} x(i) \in(0.5,0.6) \\
\frac{1-x(i)}{0.4} x(i) \in(0.6,1)
\end{array}\right.
$$

- Sine:

$$
x_{i+1}=a \sin (\pi \cdot x(i))
$$

- Sinusoid:

$$
x_{i+1}=\operatorname{ax}(i)^{n} \sin (\pi \cdot x(i))
$$

- Saw:

$$
x_{i+1}=\left\{\begin{array}{c}
\alpha \cdot x(i) x(i) \leq \frac{1}{\alpha} \\
\alpha(x(i)-1 / \alpha) x(i)>\frac{1}{\alpha}
\end{array}\right.
$$

\section{RESULTS}

We use the CBBO algorithm to apply in the IEEE-30 bus and IEEE-118 bus system to calculate and evaluate with the other recent project. With a chaotic map, we run with the initial value in $\{0.1,0.2,0.3,0.4,0.5,0.6,0.7,0.8$, $0.9\}$.The algorithm is simulated on MATLAB
2012 R2012b and the CPU: Intel core i5, $2.4 \mathrm{Ghz}$, 2.00 GB RAM.

\subsection{IEEE-30 bus System}

The IEEE-30 bus system is available in [17] with the data in the two following tables.

Table 2. The structure of the experimented IEEE-30 bus system

\begin{tabular}{|c|c|c|c|c|}
\hline Branches & $\begin{array}{c}\text { Genera- } \\
\text { tors }\end{array}$ & $\begin{array}{c}\text { Transfo- } \\
\text { rmers }\end{array}$ & Capacitors & $\begin{array}{c}\text { Controlling } \\
\text { variables }\end{array}$ \\
\hline 41 & 6 & 4 & 9 & 19 \\
\hline
\end{tabular}

Table 3. Basic values in IEEE- 30 bus test system

\begin{tabular}{|c|c|c|c|}
\hline $\begin{array}{c}\sum_{d i} \\
(M W)\end{array}$ & $\begin{array}{c}\sum_{d i} \\
(M V A r)\end{array}$ & $\begin{array}{c}\sum_{s i} \\
(M W)\end{array}$ & $\begin{array}{c}\sum_{s i} \\
(M V A r)\end{array}$ \\
\hline 283.4 & 126.2 & 287.92 & 89.2 \\
\hline
\end{tabular}

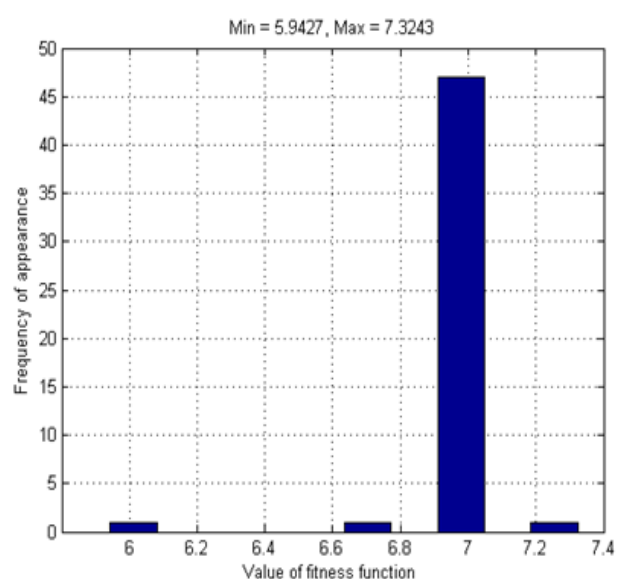

Figure 2 Values of $P_{\text {lossmin }}$ with multi running time in random $\mathrm{BBO}$

In this paper, the power flow solutions for the systems are obatined from Matpower toolbox [18]. In test system, the generators are located at buses $1,2,5,8,11,13$ and the available transformers are located on lines 6-9, 6-10, 4-12 and 27-28. The switchable capacitor banks will be installed at buses 10, 12, 15, 17, 20, 21, 23, 24 and 29 with the minimum and maximum values of 0 and $5 \mathrm{MVAr}$, respectively. The limits for controls variables are given in [20], generation active power in [21], and power flow transmisson lines 
in [22]. The number of population is set to 10 , the maximum iterations is 200 and the results were got by 50 independent runs. The comparion results were from [19].

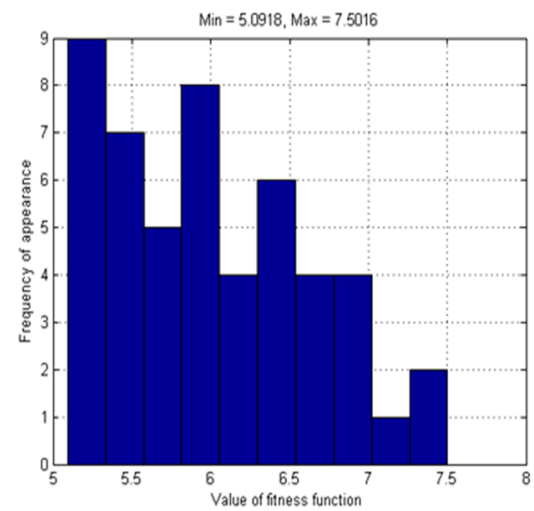

Figure 3 Values of $P_{\text {lossmin }}$ with multi running time in a random $\mathrm{CBBO}$

Two following figures shows the results of 50 independent runs of "random" BBO and a random CBBO in optimal total power loss, respectively, to clear the optimization of chaos theory to BBO.

Clearly, only $6 \%$ of solutions in $\mathrm{BBO}$ is far away the average point but the CBBO have high probability $(18 \%)$ of values near the minimum value of computing. The minimum value in CBBO is better a lot than the BBO's.

Table 4. Result by CBBO methods for the IEEE-30 bus system with power loss objective and comparison

\begin{tabular}{|l|c|c|c|c|}
\hline Method & $\begin{array}{l}P_{\text {loss min }} \\
(M W)\end{array}$ & $\begin{array}{l}\text { Voltage } \\
\text { Deviation }\end{array}$ & $\begin{array}{l}\text { Voltage } \\
\text { Stability } \\
\text { Index }\end{array}$ & $\begin{array}{l}\text { Running } \\
\text { time (s) }\end{array}$ \\
\hline CBBO & 4.94 & 0.31 & 0.14 & 30.37 \\
\hline $\begin{array}{l}\text { PSO- } \\
\text { TVIW }\end{array}$ & 4.51 & 2.05 & 0.13 & 10.98 \\
\hline $\begin{array}{l}\text { PSO- } \\
\text { TVAC }\end{array}$ & 4.53 & 1.98 & 0.13 & 10.85 \\
\hline $\begin{array}{l}\text { HPSO- } \\
\text { TVAC }\end{array}$ & 4.53 & 1.93 & 0.13 & 10.38 \\
\hline PSO-CF & 4.51 & 2.06 & 0.13 & 10.65 \\
\hline PGPSO & 4.51 & 2.06 & 0.13 & 12.21 \\
\hline
\end{tabular}

Table 5. Result by CBBO methods for the IEEE-30 bus system with voltage deviation objective and comparison

\begin{tabular}{|l|c|c|c|c|}
\hline Method & $\begin{array}{l}\text { Voltage } \\
\text { Deviation }\end{array}$ & $\begin{array}{l}P_{\text {loss nin }} \\
(M W)\end{array}$ & $\begin{array}{l}\text { Voltage } \\
\text { Stability } \\
\text { Index }\end{array}$ & $\begin{array}{l}\text { Running } \\
\text { time (s) }\end{array}$ \\
\hline CBBO & 0.19 & 6.07 & 0.15 & 18.06 \\
\hline $\begin{array}{l}\text { PSO- } \\
\text { TVIW }\end{array}$ & 0.09 & 5.84 & 0.15 & 9.97 \\
\hline $\begin{array}{l}\text { PSO- } \\
\text { TVAC }\end{array}$ & 0.12 & 5.38 & 0.15 & 9.88 \\
\hline $\begin{array}{l}\text { HPSO- } \\
\text { TVAC }\end{array}$ & 0.11 & 5.73 & 0.15 & 9.59 \\
\hline PSO-CF & 0.09 & 5.82 & 0.15 & 9.89 \\
\hline PGPSO & 0.09 & 5.80 & 0.15 & 11.11 \\
\hline
\end{tabular}

Table 6. Result by CBBO methods for the IEEE-30 bus system with voltage stability index objective and comparison

\begin{tabular}{|l|c|c|c|c|}
\hline Method & $\begin{array}{l}\text { Voltage } \\
\text { Stability } \\
\text { Index }\end{array}$ & $\begin{array}{l}P_{\text {loss min }} \\
(M W)\end{array}$ & $\begin{array}{l}\text { Voltage } \\
\text { Deviation }\end{array}$ & $\begin{array}{l}\text { Running } \\
\text { time (s) }\end{array}$ \\
\hline CBBO & 0.13 & 5.28 & 1.32 & 15.47 \\
\hline $\begin{array}{l}\text { PSO- } \\
\text { TVIW }\end{array}$ & 0.12 & 4.91 & 1.94 & 13.42 \\
\hline $\begin{array}{l}\text { PSO- } \\
\text { TVAC }\end{array}$ & 0.12 & 4.86 & 1.91 & 13.39 \\
\hline $\begin{array}{l}\text { HPSO- } \\
\text { TVAC }\end{array}$ & 0.13 & 5.26 & 1.68 & 13.05 \\
\hline PSO-CF & 0.12 & 5.00 & 1.94 & 13.39 \\
\hline PGPSO & 0.12 & 4.81 & 2.04 & 14.57 \\
\hline
\end{tabular}

The results in CBBO is presented in below table with comparing results by three criteria: total power loss, voltage deviation and voltage stability index, respectively.

\subsection{IEEE-118 bus System}

The IEEE-118 bus system is available in [17] with the data in the two following table 
Table 7. The structure of the experimented IEEE-118 bus system

\begin{tabular}{|c|c|c|c|c|}
\hline Branches & $\begin{array}{c}\text { Genera- } \\
\text { tors }\end{array}$ & $\begin{array}{c}\text { Transfo- } \\
\text { rmers }\end{array}$ & Capacitors & $\begin{array}{c}\text { Controlling } \\
\text { variables }\end{array}$ \\
\hline 186 & 54 & 9 & 14 & 77 \\
\hline
\end{tabular}

Table 8. Basic values in IEEE-118 bus test system

\begin{tabular}{|c|c|c|c|}
\hline $\begin{array}{l}\sum_{d i} \\
(M W)\end{array}$ & $\begin{array}{l}\sum Q_{d i} \\
(M V A r)\end{array}$ & $\begin{array}{l}\sum_{s i} \\
(M W)\end{array}$ & $\begin{array}{l}\sum Q_{g i} \\
(M V A r)\end{array}$ \\
\hline 4242 & 1438 & 4357.28 & 650.7 \\
\hline
\end{tabular}

Table 9. Result by CBBO methods for the IEEE-118 bus system with power loss objective and comparison

\begin{tabular}{|l|c|c|c|c|}
\hline $\begin{array}{l}\text { Metho } \\
\text { d }\end{array}$ & $\begin{array}{l}P_{\text {loss min }} \\
(M W)\end{array}$ & $\begin{array}{l}\text { Voltage } \\
\text { Deviatio } \\
\mathbf{n}\end{array}$ & $\begin{array}{l}\text { Voltage } \\
\text { Stabilit } \\
\text { y Index }\end{array}$ & $\begin{array}{l}\text { Runnin } \\
\text { g time } \\
(\mathbf{s})\end{array}$ \\
\hline CBBO & 113.93 & 0.53 & 0.07 & 143.45 \\
\hline $\begin{array}{l}\text { PSO- } \\
\text { TVIW }\end{array}$ & 116.65 & 2.07 & 0.06 & 91.72 \\
\hline $\begin{array}{l}\text { PSO- } \\
\text { TVAC }\end{array}$ & 124.33 & 1.43 & 0.07 & 85.32 \\
\hline $\begin{array}{l}\text { HPSO- } \\
\text { TVAC }\end{array}$ & 116.20 & 1.86 & 0.07 & 85.25 \\
\hline $\begin{array}{l}\text { PSO- } \\
\text { CF }\end{array}$ & 115.65 & 2.13 & 0.06 & 91.86 \\
\hline
\end{tabular}

The limits of variables is similar with IV.a. The limits for controls variables are given in [20], generation active power in [21], and power flow transmisson lines in [22]. The number of population is set to 30 , the maximum iterations is 200 and the results were got by 50 independent runs. The comparion results were from [19].

Table 10. Result by CBBO methods for the IEEE-118 bus system with voltage deviation objective and comparison

\begin{tabular}{|l|c|c|c|c|}
\hline Method & $\begin{array}{l}\text { Voltage } \\
\text { Deviation }\end{array}$ & $\begin{array}{l}P_{\text {loss min }} \\
(M W)\end{array}$ & $\begin{array}{l}\text { Voltage } \\
\text { Stability } \\
\text { Index }\end{array}$ & $\begin{array}{l}\text { Running } \\
\text { time (s) }\end{array}$ \\
\hline CBBO & 0.48 & 130.02 & 0.07 & 74.22 \\
\hline PSO-TVIW & 0.19 & 176.46 & 0.07 & 78.49 \\
\hline
\end{tabular}

\begin{tabular}{|l|c|c|c|c|}
\hline $\begin{array}{l}\text { PSO- } \\
\text { TVAC }\end{array}$ & 0.39 & 179.80 & 0.07 & 78.70 \\
\hline $\begin{array}{l}\text { HPSO- } \\
\text { TVAC }\end{array}$ & 0.21 & 146.81 & 0.07 & 74.90 \\
\hline PSO-CF & 0.18 & 164.97 & 0.07 & 78.13 \\
\hline
\end{tabular}

Table 11. Result by CBBO methods for the IEEE-118 bus system with voltage stability index objective and comparison

\begin{tabular}{|l|l|l|l|l|}
\hline Method & $\begin{array}{l}\text { Voltage } \\
\text { Stability } \\
\text { Index }\end{array}$ & $\begin{array}{l}P_{\text {loss min }} \\
(M W)\end{array}$ & $\begin{array}{l}\text { Voltage } \\
\text { Deviation }\end{array}$ & $\begin{array}{l}\text { Running } \\
\text { time (s) }\end{array}$ \\
\hline CBBO & 0.07 & 125.71 & 1.06 & 146.57 \\
\hline $\begin{array}{l}\text { PSO- } \\
\text { TVIW }\end{array}$ & 0.06 & 183.87 & 1.38 & 119.66 \\
\hline $\begin{array}{l}\text { PSO- } \\
\text { TVAC }\end{array}$ & 0.06 & 184.56 & 1.21 & 119.22 \\
\hline $\begin{array}{l}\text { HPSO- } \\
\text { TVAC }\end{array}$ & 0.06 & 155.39 & 1.34 & 1119.16 \\
\hline $\begin{array}{l}\text { PSO- } \\
\text { CF }\end{array}$ & 0.06 & 203.72 & 1.54 & 119.86 \\
\hline
\end{tabular}

The results in $\mathrm{CBBO}$ is presented in below table with comparing results by three criteria: total power loss, voltage deviation and voltage stability index, respectively.

\section{CONCLUSIONS}

In this paper, a new artificial intelligence based method BBO has been presented with full overview and results. With the optimization by chaos theory, CBBO have high probability for searching and approach the minimum value of objective function of the ORD probem better than BBO algorithm. For the result comparison, the method is shown more useful with the large searching space with more variables althoungh the $\mathrm{CBBO}$ is not effective in searching voltage deviation and voltage stability index value. By testing on the IEEE-30 bus and IEEE-118 bus systems, the proposed method has shown that it is more effective for large scale systems. Therefore, the proposed CBBO is very favoable for solving the large-scale ORPD problem. 


\section{Điều độ tối ưu công suất kháng sử dụng phương pháp tối ưu hóa dựa trên địa sinh học và lý thuyết hỗn loạn}

\section{- Trương Xuân Quý}

- Võ Ngọc Điều

Trường Đại học Bách Khoa - ĐHQG-HCM, Việt Nam

\section{TÓM TÁ́T}

Bài báo đề xuất phương pháp tối ưu hóa dựa trên địa sinh học hỗn loạn (CBBO) để giải bài toán điều độ tối ưu công suất kháng (ORPD). Trên cơ sở lý thuyết tối ưu dựa trên địa sinh học (BBO) do Dan Simon đề xuất năm 2008, một phương pháp thông minh nhân tạo mới với đầy đủ mô hình và các phương trình được áp dụng để đạt được lời giải tốt nhất cho hàm muc của bài toán ORPD như tổng tổn thất công suất, độ lệch điện áp và chỉ số ổn định điện áp thỏa mãn các ràng buộc khác nhau cân bằng công suất, giới hạn điện áp, giới hạn các bộ đổi nấc máy biến áp,

Từ khóa: Điều độ tối ưu công suất kháng, Tồi ưu hóa dựa trên địa sinh học, Lý thuyết hỗn loạn, Tổn thất công suất, Độ lẹch điện áp, Chỉ số ổn định điện áp.

\section{REFERENCES}

[1]. J. Nanda, L. Hari, and M. L. Kothari, Challeging algorithm for optimal reactive power dispatch through classical coordination equations, IEE Proceedings - C, vol. 139, no. 2, pp. 93-101, (1992).

[2]. Langfang Li, Ling Wang, Chao Sheng, Wen Sun, and Yuan Li, Analysis on voltage deviation inactive distribution network and active voltage management, China International Conference on Electricity Distribution (CICED), pp. 1610-1614, (2014).

[3]. Puraja A. J, and Vaidya G., Voltage stability index of radial Distribution network, và giới hạn công suất các tụ bù ngang. Phương pháp BBO được tăng cường khả năng tìm kiếm bằng cách thêm lý thuyết hỗn độn. Vì vậy, phương pháp CBBO có thể đạt được chất lượng lời giải tốt hơn phương pháp BBO cho các bài toán tối ưu. Phương pháp đề xuất $C B B O$ được áp dụng tính toán cho các hệ thống chuẩn IEEE 30 nút và IEEE 118 nút và kết quả đạt được đã được chứng với các phương pháp khác. Từ kết quả so sánh cho thấy rằng $\mathrm{CBBO}$ là một phương pháp đầy hứa hẹn để giải bài toán ORDP. 
[6]. S. Granville, Optimal reactive power dispatch through interior point methods, IEEE Trans. Power Systems, vol .9, no. 1, pp. 136-146, (1994).

[7]. F. C. $\mathrm{Lu}$ and Y. Y. Hsu, Reactive power/voltage control in a distribution substation using dynamic programming, IEE Proc. Gen. Transm. Distrib., vol. 142, no. 6, pp. 639-645, (1994).

[8]. N. Grudinin, "Reactive power optimization using successive quadratic programming method", IEEE Trans. Power Systems, vol. 13, no. 4, pp. 1219-1225, 1998.

[9]. Ismail Musirin, Titik Khawa Abdul Rahman, "Evolutionary Programming Optimization Technique for Solving Reactive Power Planning in Power System", 6th WSEAS Int. Conf. on Evolutionary Computing, Lisbon, Portugal, June 16-18, pp. 239-244, 2005.

[10].Abdullah, W.N.W, Saibon, H., Zain A.A.M., and Lo K.L, Genetic algorithm for optimal reactive power dispatch. Energy Management and Power Delivery, Proceedings of EMPD '98. International Conference on, vol. 1, no. 1, pp. 160-164, (1998).

[11].Messaoudi Abdelmoumene, Belkacemi Mohamed, and Azoui Boubakeur, Optimal Reactive Power Dispatch Using Differential Evolution Algorithm with Voltage Profile Control, I.J. Intelligent Systems and Applications, pp. 28-34, (2013).

[12].A.A. Abou El-Ela, A.M. Kinawy, and M.T. Mouwafi, Optimal Reactive Power Dispatch Using Ant Colony Optimization Agorithm, Proceedings of the 14th International Middle East Power Systems Conference (MEPCON 10), Egypt, December 19-21, Paper ID 315, (2010).

[13].James Kenedy, and Russell Eberhart, Particle Swarm Optimization, (1995).
[14].Dan Simon, Biogeography-Based Optimization, Evolutionary Computation, IEEE Trans.,vol. 12, issue. 6, pp. $702-713$, (2008).

[15].Wlodzimierz Bryc, The Normal Distribution - Characterizations with Applications, Springer - Velag, (1995).

[16]. Shahrzad Saremi, Seyedali Mirjalili, Andrew Lewis, Biogeography-based optimization with chaos, Neutral Comput \& Applic, vol. 25, pp. 1077-1097, (2014).

[17].Dabbagachi and R. Christie, Power systems test case archieve, University of Washington, (1993).

[18].R. D. Zimmerman, C. E. Murillo-Sanchez, and R. J. Thomas, Matpower's extensible optimal power flow architecture, In Proc. Power and Energy Society General Meeting, IEEE, pp. 1-7, (2009).

[19].Võ Ngọc Điều, Lê Anh Dũng, Vũ Phan Tú, Áp dụng phuơng pháp tối ưu hoá phần tử bầy đàn với hệ số giới hạn cho bài toán tối ưu công suất phản kháng, Tạp chí Phát triển Khoa học \& Công nghệ, vol. 2, pp. 89-101, (2013).

[20].A. Abou El Ela, M. A. Abido, and S. R. Spea, Differential evolution algorithm for optimal reactive power dispatch, Electric Power Systems Research, vol. 81, no. 2, pp. 458464, (2011).

[21].K. Y. Lee, Y. M. Park, and J. L. Ortiz, A united approach to optimal real and reactive power dispatch, IEEE Trans. Power Apparatus and Systems, vol. PAS-104, no. 5, pp. 1147-1153, (1985).

[22].O. Alsac and B. Stott, Optimal load flow with steady-state security, IEEE Trans. Power Apparatus and Systems, vol. 93, pp. 745751, (1974). 